\title{
EQUESTRIAN INJURIES: A COMPARISON OF PROFESSIONAL AND AMATEUR INJURIES IN BERKSHIRE
}

\author{
M. R. WHITLOCK, FRCSI* , J. WHITLOCK, FFARCS + and B. JOHNSTON, BSc**' \\ *Registrar in Accident and Emergency, ${ }^{*}$ Clinical Research Assistant, Wexham Park Hospital \\ tSenior Registrar in Anaesthetics, St. Mary's Hospital, Paddington
}

\section{ABSTRACT}

A retrospective study of horse riding injuries in Berkshire was undertaken over a one year period from November 1983. The information was obtained from the Ambulance Service, the Jockey Club and the St. John Ambulance Brigade. There was a total of 103 injured persons with no deaths. Information from the Jockey Club was compared with the other two groups, the former sustaining more limb injuries and the latter more head injuries. A questionnaire was sent to all 42 ambulance patients. Thirty-eight had radiographs taken, 16 of which showed a fracture. Forty-one were wearing some form of hard hat, but if a safety strap was available it was attached in 24 cases. The dangers of riding are highlighted and the importance of adequate protective clothing emphasised.

Key words: Horse riding, Injuries, Prevention.

\section{INTRODUCTION}

Horse riding is considered to be one of the most dangerous sports in this country (Firth, 1985). In 1982 there were 19 deaths reported compared with seven deaths in motor sports over the same period. There have been several studies of riding accidents with somewhat conflicting findings. Barber reported on injuries requiring in-patient treatment at the Radcliffe Infirmary, Oxford (Barber, 1973). He found that they were more common and more severe than generally appreciated and the injuries were comparable to those sustained by motor cyclists. Some Swedish workers investigated the accidents associated with riding schools in Malmo and considered the risks involved were no greater than for most other sports (Danielsson and Westlin, 1973). However, others disagreed and found the injuries were much more serious (Gierup et al, 1971). The most common severe injury was to the head, often associated with a lack of protective head gear (Grossman et al, 1978). In this country Edixhoven looked at riding injuries treated at the Newmarket General Hospital and found that most of the lesions involved the upper part of the body (Edixhoven et al, 1981). In a survey of riding fatalities in Southern Australia over an eleven-year period Pounder found that most of these were the result of a severe head injury, the majority not wearing protective head gear (Pounder, 1984).

\section{METHODS}

A retrospective study of equestrian injuries in Berkshire was undertaken over a one year period from November, 1983. The sources of information were the Ambulance Headquarters at Bracknell, the Jockey Club of Great Britain (Dr. Michael Allen) and the St. John Ambulance Brigade. A questionnaire was sent to the first group (ambulance cases) which asked for details of the cause of the accident and safety equipment used. The hospital records and ambulance report forms were used to check this information. The Jockey Club keeps accurate records of accidents to professional jockeys at race meetings and it was considered unnecessary to send these riders a questionnaire. The safety hats used are all standard and

*Present address, and for correspondence:

M. R. Whitlock, FRCSI

Accident and Emergency Services

East Birmingham Hospital

Bordesley Green East

BIRMINGHAM B9 5ST compulsory. There was a total of six meetings at Ascot, Newbury and Windsor. It should be noted that the winter was severe and some meetings were cancelled.

\section{RESULTS}

A total of 103 injured riders were analysed in 3 groups; 32 were professional jockeys and the rest amateur riders. There were no deaths. Table I shows the distribution of injuries in the 3 groups. Twenty-nine of the ambulance cases (amateur riders) involved injuries to the head and face. The majority of the jockey injuries were to the limbs (19) with only seven involving the head and face. Emergency neurosurgery was required in one patient who subsequently recovered. Surgery was necessary at a later date for all the facial fractures. Spinal injuries were more common in the ambulance cases (10/69) compared with the professional jockeys (2/35). The two spinal fractures involved the lumbar spine. Both these patients sustained partial paralysis which had not fully recovered one year later.

\section{TABLE I}

The injuries sustained in the $(n=59)$ amateur horsemen/women brought to hospital by the emergency ambulance, in professional jockeys ( $n=32$ ) and in persons involved in riding accidents reported by the St. John Ambulance Brigade (n = 12).

\begin{tabular}{|c|c|c|c|c|c|}
\hline & $\begin{array}{l}\text { Amat } \\
\text { No. }\end{array}$ & $\begin{array}{l}\text { H Horsemen } \\
\text { Fractures }\end{array}$ & $\begin{array}{l}\text { Profes } \\
\text { No. }\end{array}$ & $\begin{array}{l}\text { Onal Jockeys } \\
\text { Fractures }\end{array}$ & $\begin{array}{c}\text { Riding } \\
\text { Accidents } \\
\text { No. }\end{array}$ \\
\hline Head injury alone & 14 & 4 & 3 & 1 & 2 \\
\hline Facial injury alone & 7 & 5 & 3 & 2 & 4 \\
\hline $\begin{array}{l}\text { Head and facial } \\
\text { injury }\end{array}$ & 8 & 6 & 1 & 0 & 1 \\
\hline Spinal injury & 10 & 2 & 2 & 0 & 1 \\
\hline Upper limb injury & 10 & 9 & 12 & 4 & 0 \\
\hline Lower limb injury & 5 & 2 & 9 & 3 & 1 \\
\hline Chest injury & 7 & 4 & 2 & 0 & 2 \\
\hline Pelvic Injury & 5 & 5 & 2 & 0 & 0 \\
\hline Abdominal injury & 3 & 0 & 1 & 0 & 1 \\
\hline Shoulder injury & 0 & 0 & 0 & 0 & 2 \\
\hline Total & 69 & 37 & 35 & 10 & 14 \\
\hline
\end{tabular}

The questionnaire sent to the 59 ambulance (amateur) cases had a $71 \%$ return rate (Table II). There appeared to be little seasonal variation, except for July when only one injury was recorded. Thirty-five of the injuries occurred at weekends. On most occasions the weather conditions were 
clear, but in 12 cases it was raining. Forty-one patients were female. The average age was 24.4 years with a range of 12 to 47. Twenty-five needed hospitalisation for at least one night. Fifty-five had radiographs taken, 31 of which revealed a fracture. Only 28 of the 42 that completed the questionnaire said that they had completely recovered. Those that had not recovered fully complained mostly of limitation of movement. In all of the head injury patients there were neurological symptoms including headaches $(5$ patients).

TABLE II

Questionnaire to ambulance patients (42 returned).

\begin{tabular}{llr}
\hline & & No. \\
Location & Road & 11 \\
& Field & 15 \\
& Stables & 8 \\
& Competition & 8 \\
Mechanism of injury & Thrown by horse & \\
& (reared/bolted) & 15 \\
& Jumping & 15 \\
Hat & Vehicle involved & 8 \\
& Other & 4 \\
& B.S.I. Standard & 14 \\
& Old/unknown B.S.I. & 14 \\
Hat's safety strap & Other hat & 13 \\
& Nohat & 1 \\
& Attached & 10 \\
& Not attached & 31 \\
& Unknown & 1 \\
\hline
\end{tabular}

\section{DISCUSSION}

There is no doubt that horse riding is a dangerous sport. The survey of amateur riders only considered those who arrived at the hospital in an ambulance as an emergency and were likely to have sustained a serious injury and it did not include those amateur riders who may have attended hours or days later. There is a marked difference in the pattern of injuries to professional jockeys and amateur riders. Most of the jockeys sustained injuries to the limbs whereas in the remainder the lesions were mostly to the head and face. This may be a reflection of the better head protection worn by jockeys, although they usually fall on grass compared with variable surfaces in amateur riders. Spinal injuries in jockeys were also infrequent, two out of 32 compared to ten out of 59 in amateur riders. Jockeys often wear some form of spinal padding which helps to protect them from the characteristic "jockey injury" (fracture of the thoracic spine, usually the twelfth thoracic vertebra).

The Jockey Club has rigid safety standards and any jockey who is injured during a race is prohibited from racing until pronounced fit by a doctor. A reduction of head injuries to jockeys was confirmed by D'Abreu (1976). Unfortunately, the rest of the riding fraternity has been slow to follow the example of the Jockey Club, although the Pony Club has recently made it mandatory to wear a jockey hat for their events.

There were no ankle injuries in this survey which may reflect the trend by riders towards the wearing of stronger boots. Barber's survey (1973) suggested that riders were not wearing adequate footwear and our findings suggest that this may no longer be the case.

No explanation can be given for the reduction in the number of accidents in July. It is possible that Berkshire, unlike Devon, does not cater for holiday trekking and most people will take holidays during that month.

One quarter of accidents occurred on a public road. Most motorists are not aware of the dangers in passing a horse, although advice is given in the highway code which also advises hard hats to be worn. Every horse rider should follow the advice given in the British Horse Society publication "Ride More Safely", which also recommends the wearing of fluorescent belts or tabards.

Riders' hats have improved since a first minimum standard was introduced in 1963 (British Standards Institute, 1963). However, this original standard is still the most popular hat in Great Britain, despite the withdrawal of the BSI Kite Mark. This survey with its large number of head injuries highlights the limited protection provided by this hat. The British Broadcasting Corporation has recently publicised the dangers of cheap imported hats (That's Life; Esther Rantzen, 3.2.85), but these are still widely available. It is regrettable that only ten of those that had a chin strap available had it attached and this suggests that the rider's attitude to safety could be improved.

This study, accepting the limitations of retrospective information, highlights the dangers of horse riding. The large number of fractures would suggest that doctors working in Accident and Emergency Departments should treat all riding injuries as potentially serious. The different patterns of injuries in professional and amateur riders would suggest that many injuries could be prevented by better protective clothing, especially head gear.

\section{ACKNOWLEDGEMENTS}

We wish to thank Miss M. S. Christian, FRCS, and Mr. S. Knight, FRCS, of Wexham Park Hospital, for permission to review these patients and for their helpful comments. Dr. M. Allen of the Jockey Club kindly provided us with a list of injuries in the professional jockeys. Catherine Paton, BSc, compiled the information from ambulance control. We would also like to thank Mr. A. B. Cross, FRCSI, of East Birmingham Hospital for his helpful comments and Jennifer Stevens and Sally Mansell for typing the manuscript.

\section{References}

Barber, H. M., 1973 "Horse-play survey of accidents with horses". Br.Med.J. 3: $532-4$.

British Standards Institution, 1963 "Specification for protective hats for horse and pony riders". No: 3686

D'Abreu, F., 1976 "Brain damage in Jockeys". The Lancet 2: 1241

Danielsson, L. G. and Westlin, N. E., 1973 "Riding Accidents". Acta Orthop. Scand. 44: 597-603.

Edixhoven, P., Sinha, S. C. and Dandy, D. J., 1981 "Horse Injuries". Injury 12: 279-82.

Firth, J., 1985 "Equestrian Injuries" in Schneider, R. C., Kennedy, J. C. and Plant, M. L. (eds.): "Sports Injuries, Mechanisms, Prevention and Treatment", P432, First Ed., Williams and Wilkins, Baltimore.

Gierup, V., Larson, M. and Lennquist, S., 1971 "Incidence and nature of horseriding injuries". Acta Chir.Scand. 142: 57-61.

Grossman, J. A. I., Kulund, D. N., Miller, C. W., Winn, H. R. and Hodge, R. H. 1978 "Equestrian Injuries". JAMA 240: 1881-2.

Pounder, D. J., 1984 "The grave yawns for the horseman". Med.J.Aust. 141: 632-5. 